2018-12

\title{
Ivory trade: Poicy and law change
}

\author{
Lowther, Jason
}

http://hdl.handle.net/10026.1/12581

$10.1177 / 1461452918804939$

Environmental Law Review

SAGE Publications

All content in PEARL is protected by copyright law. Author manuscripts are made available in accordance with publisher policies. Please cite only the published version using the details provided on the item record or document. In the absence of an open licence (e.g. Creative Commons), permissions for further reuse of content should be sought from the publisher or author. 


\title{
Ivory trade: policy and law change
}

\author{
Jason Lowther, University of Plymouth
}

This is an unformatted version of an article published in the Environmental Law Review (2018)

\begin{abstract}
Against a backdrop of consistent NGO pressure countered by an unrelenting and increasingly transnational, organised crime-framed poaching effort, the Secretary of State for the Environment Food and Rural Affairs moved to enact legislation which will significantly curtail what remains of the market for ivory products in the UK. The Ivory Bill, at the time of writing going through its parliamentary stages, will sidestep the majority of the current exemptions, premised on the antiquity of a worked item, to the usual prohibition on the trade of raw or worked ivory which owes its existence to the Convention on the International Trade in Endangered Species of Wild Fauna and Flora 1973 (CITES) and the Treaty's domestic implementing measures. The accelerated illegal killing of charismatic species such as elephants has prompted legal responses at international and local levels in both range and destination-market states. Laws targeting both the supply and demand sides of the trade have been undermined by the trade in antique ivory: a shadow, parallel market of imitation antiques has existed for some time as a means to launder poached ivory through the exemptions to the CITES system. This short article will introduce the mechanics of the Ivory Bill, set in the context of the drivers which have prompted it, and will evaluate its potential contribution to curtailing this destructive trade.
\end{abstract}

Key words: ivory, endangered species, trade, CITES, Ivory Bill

\section{Introduction and context}

Elephant populations are in significant decline. Research from the Great Elephant Census published in 2016 reported a 'massive decline' in African savannah elephant numbers across several range states. ${ }^{1}$ From 2007 to 2017 there has been an estimated decline of 110,000 to 144,000 elephants, or 8 percent per annum. This decline is primarily attributed to poaching. ${ }^{2}$ The research reported that of those elephants included in the census, 84 percent were resident in protected areas of one form or another and that the best outcomes for the species would be secured though combatting poaching. In addition, the International Union for the Conservation of Nature's 2016 African Elephant Status Report noted that it was the first time in 25

\footnotetext{
${ }^{1}$ Chase et al., 'Continent-wide survey reveals massive decline in African savannah elephants', PeerJ 4:e2354 (201) peerj.2354DOI 10.7717/:

2 Ibid.
} 
years that a continental decline in elephant numbers had been recorded. ${ }^{3}$ The report is clear as to the cause, observing that the decline is largely caused by the surge in poaching for ivory that began around 2006...the worst that Africa has experienced since the 1970s and 1980s'. ${ }^{4}$ It may be that interventions by countries such as the United States and China to ban the majority of their domestic ivory markets are having an impact. The Monitoring of the Illegal Killing of Elephants Programme(the MIKE programme ), established out of the $10^{\text {th }}$ Conference of the Parties to the Convention of the international Trade in Endangered Species of Wild Fauna and Flora 1973 $(\text { CITES })^{5}$, collects data on elephant mortality and makes projections on possible causes of death. The most recent statistics would appear to confirm a gradual decline in illegal killing after a few years of increase, but the impact on numbers remains significant in African range states. ${ }^{6}$ Increased poaching effort is driven by the worldwide trade in ivory, which shows little sign of diminishing according to a TRAFFIC report to the CITES Standing Committee. ${ }^{7}$ Demand is primarily, though not exclusively, located in large Asian markets in China, Japan and the special administrative region of Hong Kong. ${ }^{8}$

\section{CITES}

The following provides a brief overview of CITES in so far as it relates to elephants and ivory products. The Convention regulates the international trade in certain species of wild plants and animals, which includes live specimens, parts or derivatives. There are currently 183 parties to the Convention, including the EU. The level of regulation applied to the trade in a particular species depends on where it is placed in CITES' three appendices, which correlate to its survival status. Broadly, Appendix I lists species threated with extinction which are or may be affected by trade; consequently their trade is permitted only exceptionally. Appendix II species are those which are not currently threatened with extinction, but may become so unless trade is regulated and Appendix III concerns those species which are regulated within the jurisdiction of a state party in order to prevent or restrict exploitation and that international trade restrictions would assist. ${ }^{9}$ Trade in the species listed in the appendices may only be

\footnotetext{
3 Thoules, C.R et al., African Elephant Status Report 2016, IUCN Species Survival Commission, Occasional paper No.60 (2016) IUCN. Available at https://portals.iucn.org/library/sites/library/files/documents/SSC-OP-060 A.pdf (Accessed July 2018). ${ }^{4}$ lbid at 10.

5 Washington, $197310^{\text {th }}$ Conference to the Parties, Harare, Conf. 10.10. See generally https://cites.org/eng/prog/mike/about-mike (Accessed July 2018).

${ }^{6}$ CITES, MIKE Report, Levels and Trends of Illegal Killing of Elephants in Africa to December 2016preliminary findings. Available at https://cites.org/sites/default/files/eng/prog/MIKE/MIKE report released WWD 3Mar2017.pdf (Accessed August 2018).

${ }^{7}$ Status of elephant populations, levels of illegal killing and the trade in ivory: a report to the cites standing committee, SC69 Doc 51.1. Available at https://cites.org/sites/default/files/eng/com/sc/69/ESC69-51-01-A.pdf (Accessed August 2018).

${ }^{8}$ Lau (et al), A rapid survey of UK ivory markets, 2016, TRAFFIC, Cambridge UK. Page VIII. Available at http://www.trafficj.org/publication/16 A Rapid Survey of UK Ivory Markets.pdf (Accessed August 2018)

${ }^{9}$ CITES, Article II (1-3).
} 
conducted pursuant to the Convention ${ }^{10}$ and Article VIII requires parties to prohibit trade not in accordance with its provisions, including measures to penalize trade in and/or possession of specimens, as well as allowing for confiscation and, where necessary, repatriation to the country of export.

Virtually all elephant species are listed in Appendix I of CITES meaning that that they are subject to the most stringent restrictions upon their trade. ${ }^{11}$ Article III provides the detail, but for the sake of brevity, export, import and re-export permits must be granted by the relevant authorities in the respective states. ${ }^{12}$ Those permits may only be granted subject to the satisfaction of a number of conditions relating to the impact of the survival status of the species; if a live specimen, the conditions of shipment and housing on destination and, importantly, that the specimen is not to be used for primarily commercial purposes. ${ }^{13}$ Certain exemptions are provided for in Article VII: those relevant to the discussion here are specimens that were acquired before CITES provisions applied to them (known as pre-Convention specimens) and specimens that are personal or household effects.

\section{EU Wildlife Trade Regulations}

The EU implements the provisions of CITES through a series of Regulations (the Regulations) adopted prior to the EU's accession to the Convention in 2015. ${ }^{14}$ The Regulations follow the form of the Convention, although the former contains additional species in its appendices, and adopts a more strict line in respect of certain aspects of trade. The stringent controls on elephant ivory are thus manifested in the Regulations: the trade in ivory is generally proscribed within (or to or from) the EU for any commercial purpose. However, there are exceptions relating to intra-EU trade and re-export of items for commercial purposes when these conform to certain specified conditions. First, intra-EU trade is permitted in the case of antique ivory. This would essentially be a worked specimen that was acquired before 1947 or an item of ivory which was imported into the EU before elephant species were listed in CITES' Appendix I. ${ }^{15}$ Re-export from the EU is permitted if the antique ivory fulfils those same criteria. ${ }^{16}$

\section{UK Implementing Regulations}

\footnotetext{
10 lbid, II (4).

${ }^{11}$ Populations in Zimbabwe, South Africa, Namibia and Botswana are included in Appendix II.

${ }_{12}$ CITES, Article III (1-4). Introduction from the sea is also contemplated but not considered here.

CITES identifies two authorities: the Scientific and Management Authorities respectively. The UK's bodies include the JNCC and Defra.

13 Ibid, III (3)(c)

${ }^{14}$ The basic (consolidated Regulation is Council Regulation (EC) No 338/97 of 9 December 1996 on the protection of species of wild fauna and flora by regulating trade therein (OJ L 1997, 61/1). For the full range of measures - beyond the scope of this piece - see the Commission's pages relating to CITES implementation at http://ec.europa.eu/environment/cites/legislation en.htm (Accessed August 2018).

${ }^{15}$ Respectively Article 8(3)(b) and (a).

${ }^{16}$ Article 5(6).
} 
The Control of Trade in Endangered Species (Enforcement) Regulations 1997 (COTES) are the UK's implementation vehicle, creating offences as required by the EU's Regulation. ${ }^{17}$ The penalties for COTES offences were strengthened in 2005, providing for a six month maximum term of imprisonment, and/or a fine, for summary convictions, rising to 5 years, and/or a fine for conviction on indictment. ${ }^{18}$ Despite the significance given to such offences, it has recently been claimed that the UK is the largest supplier to ivory markets worldwide as a result of the use of the exemptions. ${ }^{19}$

The antique/historic exemption to the trade restrictions has given rise to a so-called shadow market: where sales of legitimate items provide the cover for organised criminality to offer items for sale which are misrepresented as falling within those categories. ${ }^{20}$ That shadow market is fed by contemporary poaching efforts. Until relatively recently testing has been both difficult and expensive and a proliferation of ivory sales online has been charted for more than a decade, with the most recent investigation estimating in excess of 1200 ivory items for sale across the UK, France, Germany and Russia. ${ }^{21}$ Alongside the threats to the species involved, the current impetus to take action on ivory poaching are is driven by what might be termed compound threats. Amongst those identified are organised criminality, disruption of civic society and the risk that funds raised are funnelled towards terrorist organisations. In 2014 the London Declaration, following a high level wildlife crime conference stated: '...Poaching and trafficking undermines the rule of law and good governance, and encourages corruption. It is an organised and widespread criminal activity, involving transnational networks. The proceeds are in some cases used to support other criminal activities, and have been linked to armed groups engaged in internal and cross border conflicts. ${ }^{22}$

Against this backdrop in 2015, the United States and China gave notice of their intentions to severely restrict imports and exports of ivory. The EU is considering further action, France has implemented measures and there has been a resolution (non-binding) through the CITES process to curtail domestic ivory markets amongst the state parties. The remainder of this piece will set out the UK's policy response and the basics of the Ivory Bill currently before Parliament.

\section{Policy Responses}

\footnotetext{
17 S.I. 1997/1372 (as amended).

18 The Control of Trade in Endangered Species (Enforcement) (Amendment) Regulations 2005, S.I. 2005/1674.

${ }_{19}$ See for example the release by the Environmental Investigation Agency in 2017, https://eiainternational.org/uk-largest-supplier-worlds-ivory-markets (accessed August 2018).

20 See for example: WWF/TRAFFIC, Crime and Punishment in the Wildlife Trade, 2002, London. International Fund for Animal Welfare, Elephants on the High Street, 2004, London.

21 International Fund for Animal Welfare, Caught in the Web, 2005, London; International Fund for Animal Welfare, Disrupt: Wildlife Cybercrime, 2018, London.

22 The London Declaration 2014, paragraph 2. Available at https://www.gov.uk/government/publications/declaration-london-conference-on-the-illegal-wildlifetrade (Accessed August 2018).
} 
Both the European Commission and the Defra consulted on the ivory trade in late 2017. The focus of the consultations differed slightly but the general purpose was concerned with demand and supply reduction measures through limiting the ivory trade still further. The Commission's consultation was broader in remit, considering the mechanics of both the legal and illegal trade within and from the EU and a consideration of priorities for tackling it. The exercise was referential to the Commission's 2016 Action Plan against Wildlife Trafficking, specifically the objective of reducing supply and demand of illegal wildlife products and taking action on the trade in ivory. ${ }^{23}$ At the time of writing the full synopsis report of the consultation is not available, however the Commission has published a short factual summary report. ${ }^{24}$

The Defra consultation was more limited in scope. Its stated purpose was to seek views in respect of the government's proposal to implement a total ban on ivory sales in the UK 'where such sales could contribute either directly or indirectly to the poaching of elephants'. ${ }^{25}$ It also considered the exemptions to the general rule that might be applied and the enforcement and sanctions regime that should be applied to the ban. In addition there was a call for evidence on the effect of an ivory sales ban on elephant conservation, natural environment and business, to include 'its economic and cultural effect'. ${ }^{26}$

Support for a ban was significant with over 87 percent of respondents supportive of the government's proposal. Interestingly, only a minority of the respondents supported one or other of the proposed categories of exempt materials, with around 10 percent opposed to any exemption. ${ }^{27}$ The exemptions have survived, as will be discussed in the next section which considers the Ivory Bill introduced before parliament following the consultation. In terms of the effects of a ban on elephant conservation, the responses reflected a number of the phenomena outlined above: organised criminality and corruption, shadow markets and the complementary effect of the removal of a legal trade. ${ }^{28}$ Evidence of the impact of bans in other jurisdictions was cited to reflect both a momentum against the ivory trade and the extent to which those bans have been successful in decreasing the volume of material for sale. For example, in the United States, a survey undertaken in 2016 demonstrated that the number of items offered for sale in retail outlets in-store (as opposed to online) had diminished by around 97 percent since 2006-2007, following the US federal ban, . ${ }^{29}$

Both economic and cultural implications were considered, with evidence reported in respect of the value to African range states' tourism. The elephant's place amongst

${ }^{23} \operatorname{COM}(2016) 87$ final, Communication from the Commission, EU Action Plan against Wildlife Trafficking, Brussels 26.2.2016 (Accessed August 2018)

24 The report, by DG Environment is available at https://ec.europa.eu/info/consultations/publicconsultation-ivory-trade-eu en (Accessed August 2018)

25 Defra, Banning UK sales of livory. Summary of responses and Government response, April 2018.

Available at www.gov.uk/government/publications (Accessed August 2018)

26 Ibid 1.

$27 \mathrm{lbid}$ at3.

28 lbid at $4-5$

29 Ibid at7 citing Kramer, R (et al), The US elephant ivory market: A new Baseline, 2017, TRAFFIC,

Washington DC. Available at

https://www.traffic.org/site/assets/files/1378/traffic us ivory report 2017.pdf (Accessed August 2018). 
the so-called 'Big 5' of safari animals is essentially a guaranteed pull for tourists which then creates a significant local and sustainable financial benefit. ${ }^{30}$ The research is clear that short-term protection will undoubtedly maintain economic benefits of tourism in the range states, while a more general conservation agenda will broaden sustainable tourism into the longer term. The authors conclude that 'well-established and capitalized conservation businesses, for instance, are increasingly delivering financial benefits and guaranteeing employment to local communities helping achieve human and economic development'. ${ }^{31}$

Opposition to the proposals to ban the trade generally centred on the potential financial losses which would fall upon individuals and/or those in the antiques business with ivory holdings. The loss of value in the product could, it was submitted, represent an infringement of property rights. It would appear to be a well-founded concern. An outright ban, including a restriction on trade in pre-1947 specimens would mean that those possessing ivory items would essentially lose any value in them. The US experience referred to above, and a study cited in the consultation response on the French experience, strongly indicate that this would be the impact. ${ }^{32}$ However, antique dealers do not only sell ivory, and it was reported that that 'very few, if any' members of the British Art Market Federation specialise in ivory products - something also cited by other trade body respondents. ${ }^{33}$ It was reported that there is no clear figure available on the value of the trade or the number of items sold in the UK. Research over the last decade has indicated that the trade is in decline, with both the value of sales at auction houses and the number of physical outlets offering ivory for sale having diminished, although the research noted that there may be a shift to online trading methods. ${ }^{34}$ The remainder of the consultation was concerned with more specific matters relevant to the operation of the proposed trade restriction, the exceptions to it and the enforcement of it were it to become law. Respondents' views will be included alongside the outline explanation of the Ivory Bill in the following section.

\section{The Ivory Bill}

The Ivory Bill was introduced before Parliament by the Secretary of State for the Environment in late May 2018. It completed its stages in the House of Commons with cross-party support and had a second reading in the House of Lords in July $2018 .{ }^{35} \mathrm{It}$ is scheduled for the Lords' Committee later in the autumn. Essentially the Bill is

\footnotetext{
30 Ibid at8 citing, Di Minin, E, (et al) (2013) Understanding Heterogeneous Preferences of Tourists for Big Game Species: Implications for Conservation and Management. Animal Conservation, 16(3), 249258. The 'Big 5' being lion, elephant, buffalo, leopard, rhinoceros.

31 De Minin et al at256.

32 Above n. 25 at 9.

33 Ibid at 11.

${ }^{34}$ Ibid, citing Lau (et al), at 31 . Available at http://www.trafficj.org/publication/16 A Rapid Survey of UK Ivory Markets.pdf (Accessed August 2018).

35 House of Lords Hansard, 17 July 2018, Volume 792, Column 1144. Available at https://hansard.parliament.uk/lords/2018-07-17/debates/32EEC7EF-60FC-498A-B44213F179F601CE/lvoryBill (Accessed August 2018).
} 
arranged over 42 clauses with two schedules and creates a prohibition on dealing in ivory subject to a limited number of relatively tightly prescribed exemptions. The Bill establishes criminal offences, although there is scope for the application of civil sanctions. The detail of the measures will be explored in more detail below.

Clause 1 introduces the prohibition on dealing in ivory. Ivory is defined in c. 35 as 'ivory from the tusk or tooth of an elephant'. While this is currently limited to elephant species, ${ }^{36}$ the Bill provides that the Secretary of State may extend that definition to 'ivory' from other species by way of regulation. ${ }^{37}$ Interestingly, if an item is deemed to be ivory from any animal a (rebuttable) presumption is raised that it is ivory from an elephant. ${ }^{38}$ 'Dealing' is given a broad meaning and includes, buying, selling (both defined) or hiring as well as offering (defined) to do any of those things. Alongside that, the definition encompasses keeping for sale or hire as well as import and export to or from the UK. ${ }^{39}$ Buying or hiring outside of the UK in not included in the definition, while selling or hiring is.

The exemptions to the prohibition follow in clauses 2-9. The first concerns pre-1918 items of outstanding artistic value and importance. An ivory or ivory containing item is made exempt if the Secretary of State has issued an exemption certificate. According to clause 2(2) the Secretary of State must be satisfied both as to the age of the piece and that the item is 'of outstandingly high artistic, cultural or historical value', which would on the face of it appear to set a very high bar. Making that determination is subject to a consideration of issues such as the rarity of the item and its exemplary nature. The Secretary of State is empowered to issue guidance in this respect and may prescribe institutions with expert knowledge to advise on applications for certificates. ${ }^{40}$ The issuing of exemption certificates may only occur on application: potentially providing a means by which to gain a record of existing ivory items. ${ }^{41}$ At the consultation stage, a majority of respondents were against such an exemption on the basis, amongst others, that it would be nebulous and provide a loophole to enable illegal trade. There was also an expression of the need to change attitudes to ivory. Having the exemption cast in these terms, it was suggested, would maintain the status of ivory as a luxury commodity. Ultimately, the exemption survived the consultation, underpinned by the certification scheme, the detail of which is set out in clauses 3-5 of the Bill.

Four further exemptions are provided for. Three of these are primarily focused on the fact that there is a low ivory content, although there are further conditions which apply. The first is in respect of pre-1918 portrait miniatures - popular items in the years predating photography. Respondents to the consultation were generally supportive of an

\footnotetext{
36 Itself defined in c 35(5)(a).

${ }^{37}$ Clause 35(2) - for example, scrimshaw items, made from whale ivory (teeth or baleen), are regulated pursuant to CITES and the EU Regulation, and could theoretically later be included. ${ }^{38}$ Clause 35(4).

39 Clause 1(1) - in addition c.33 applies the Customs and Excise Management Act 1979 provisions for the breach of a prohibition on importing and exporting certain items. The Act has been used successfully in the past in respect of imports of CITES-listed species, see eg $R v$ Sissen [2000] EWCA Crim 67 - a case brought under s170(2) of the Act.

40 Clauses 2(3)(b) and 2(5) respectively.

${ }^{41}$ Clause 2(4).
} 
exemption applying to portrait miniatures as the ivory content was so low as not to be worth re-carving, thus not contributing to a general 'ivory' market. Clause 6 provides an exemption from the prohibition if the item is a pre-1918 portrait miniature with a surface area of no more than $320 \mathrm{~cm}^{2}$, and that it is registered accordance with a process set out clause 10. The cultural significance here would appear to be comprised in the item as opposed to its ivory content. In a similar fashion, the Bill next provides for the exemption of pre-1947 items with a very low ivory content. The de minimis exemption threshold is set at 10 percent. In the government's view this would also facilitate enforcement. Although responses to the consultation were mixed, they were considered in the framing of the exemption. Any ivory contained within an item must be integral to it: defined in clause $7(2)$ as being such that '...it could not be removed from the item without difficulty or without damaging the item'. Once again, the item must be registered pursuant to clause 10 . Finally within this category of exemptions is an item containing ivory which is a pre-1975 musical instrument. The 1975 date is significant as this was the year that the Asian elephant was first listed on CITES Appendix 1 - African elephants were not listed until 1989, which was the preferred backstop date of the music industry, also reportedly keen that there should be no de minimis restriction. ${ }^{42}$ Ultimately it was determined that pre-1975 musical instruments are exempt pursuant to clause $8(1)(b)$ if the volume of ivory in the instrument is less than 20 percent of the total volume of the material of which the instrument is made. A musical instrument is further defined to include the means of playing a musical instrument - such as a bow or plectrum. The definition does not extend to something which, although capable of being played as a musical instrument, was not made primarily for that purpose. For example, an antique comb containing ivory accompanied by a piece of tracing paper would be firmly outside of the exemption in that case!

The final exemption relates closely to the heritage value of the item, and was argued to be a reason to not permit the artistic value (etc.) exemption, which as noted above survived the discussion and is part of the Bill. Museums provide a place for ivory or ivory containing objects to be displayed without contributing to a commercial trade. The dealing of ivory is exempt from the prohibition according to clause 9 if the dealing is by way of sale to or hire or purchase by a qualifying museum. The material must have been owned by a qualifying museum, or have been registered pursuant to the clause 10 process, at the time of the dealing. ${ }^{43}$ To satisfy the 'qualifying' requirement, the museum must, in the case of UK, Channel Islands or Isle of Man institutions be shown to be accredited on a list published by the relevant Arts Councils or equivalents in the devolved administrations. Museums outside of the UK are required to be a member of the International Council of Museums. ${ }^{44}$ The accreditation requirements are linked to the governance and acquisitions policies required of the listed UK bodies, thereby providing a closed loop in terms of the items acquired and displayed.

Clauses 10-11 set out the registration requirements which must be followed in order for a particular item to fit any of the above exemptions. The Secretary of State must

\footnotetext{
${ }^{42}$ Above n. 25 at 13.

${ }^{43}$ Clause 9(2).

${ }^{44}$ Clause $9(3)$.
} 
(emphasis added) register the item if the owner applies and provides the required information as to identity, address and the item's description and conformity with the exemption conditions (age, volume of ivory etc) ${ }^{45}$ Changes of ownership require a further application for registration. The Animal Health and Plant Authority is to be the administrator for the registration scheme, and the database is to be accessible by the government as well as enforcement authorities, including the police and the regulator. Presumably this has significant benefits in terms of tracing and identification of items offered for sale. The Policy Statement is clear that the ban on dealing ivory will be in addition to rather than a replacement of the current CITES regulatory mechanism. The statement confirms that: 'no item that cannot be sold now, will be permitted to be sold after the ban is implemented. Items that currently need a certificate to be sold, imported or re-exported under the EU Wildlife Trade Regulations will continue to require one. This will be in addition to having to comply with the ban'. ${ }^{46}$

The principal offences are created in clause 12. It is an offence to breach the provision; to cause it to be breached or to facilitate its breach. The offence requires that the person concerned knows or suspects, or ought to know or suspect that the item is or contains ivory. Taken with clause 12(3) which introduces a due diligence defence, the offence is relatively easily made out, particularly with the addition of the constructive knowledge aspect. Penalties are robust with the possibility of a term of imprisonment up to 12 months and or a fine for summary convictions; and imprisonment for up to 5 years and/or a fine for conviction on indictment. The stated policy is for the penalties to map onto those already in existence is respect of the COTES Regulations. Alongside the criminal sanctions, the bill provides for civil sanctions to be applied where appropriate. The detail of the civil sanctions regime is contained in Schedule 1 and includes familiar devices such as stop notices, monetary penalties, to a maximum of $£ 250,000$, enforcement undertakings and the like. 47

The remainder of the Bill is concerned with the mechanics of enforcement and contains provisions in respect of the necessary powers of stop, search, entry and seizure. An offence of obstruction is included in clause 27; and there are measures relating to retention, forfeiture and return of seized items as necessary.

\section{Conclusions}

There does appear to be the glimmer of progress internationally on the ivory issue. The US, Chinese and French initiatives over the last few years represent significant inroads into the viability of the existing legal markets. The Bill contributes a further statement of intent from a significant destination and transit market that in order to curtail the ivory trade effectively, there should be an accompanying change in the perception of ivory as a tradable commodity. Altering perceptions as to the desirability of the acquisition of ivory, whether antique or otherwise, is key to the success of the measure. The rhetoric around the measures proposed in the Bill is suggestive of a will

\footnotetext{
${ }^{45}$ Clause 10(1),(2).

${ }^{46}$ Above n. 25 at 26.

${ }^{47}$ Clause 13, Schedule 1
} 
to change norms around the desirability of ivory or products containing it. Defra's policy stance is unequivocal, intending 'the UK's ivory sales ban to be amongst the toughest in the world, demonstrating that the UK does not consider commercial trade in any ivory that could fuel poaching to be acceptable'. ${ }^{48}$

As ever, effectiveness depends on the ability to enforce. As yet, there is no specific body tasked with this: the policy statement indicates that the Secretary of State will nominate an existing regulator, which would be required to work closely with existing enforcement bodies. The police and Border Force have obligations under COTES and CEMA respectively; and the National Wildlife Crime Unit, which has since its inception had a particular focus on prioritising CITES related crime..$^{49}$ It would appear that there is a genuine impetus to tackle the trade in the UK, which, if successful will undoubtedly assist in putting an end to the demand for ivory.

\footnotetext{
${ }^{48}$ Above n. 25 at 23.

${ }^{49}$ See for example UK NCWU, Current UK Priorities, available from http://www.nwcu.police.uk/howdo-we-prioritise/priorities/ (Accessed August 2018)
} 